\title{
Call for papers: Special section for the 2007 Noto Hanto Earthquake
}

We now invite you to the special section of EPS for the earthquake in the Noto Hanto, Japan, area on 25 March 2007. Any papers related to this earthquake are welcome. Since this event is closely related to previous seismic activities in this area, studies on such events in the past are also included. We shall accept only papers of the "letter" style for this special section in order to publish scientific results on these events promptly. Each letter should not exceed 6 pages in print.

Contributors to this special section should submit their papers to the editorial office of EPS, following the instructions for submission as a "letter" to the regular section. For details, please visit

http://www.terrapub.co.jp/journals/EPS and click on "Information for Contributors."

Please state in your cover letter that you submit your paper to "Special section for the 2007 Noto Hanto Earthquake" We ask you to attach the list of five potential referees of your manuscript, including two or three researchers outside Japan, if possible. We welcome electric submissions to eps@terrapub.co.jp.

Upon the acceptance of each manuscript, its corresponding author will receive instructions for the final manuscript from the editorial office. We set the final deadline for this special section on 30 June 2007, but we encourage potential contributors to submit manuscripts as soon as possible in order to be included in press. This special section will preferably be published in the 2007 October issue.

For more information, please send an email message to the Editor-in-Chief of EPS (eps-ed@belinda.sci.hokudai.ac.jp), while questions on manuscript preparation should be addressed to the EPS editorial office.

Note: EPS accepts manuscripts of original research contributions only, and so-called "review papers" will not be accepted.

Kiyoshi Yomogida, Editor-in-Chief 